\title{
Comment on a proposed draft protocol for the European Convention on Biomedicine relating to research on the human embryo and fetus
}

Mette Maria Lebech University of Copenhagen, Denmark

\begin{abstract}
fudge Christian Byk renders service to the Steering Committee on Bioethics of the Council of Europe (CDBI) by proposing a draft of the protocol destined to fill in a gap in international law on the status of the human embryo. This proposal, printed in a previous issue of the Journal of Medical Ethics ${ }^{1}$ deserves nevertheless to be questioned on important points. Is Christian Byk proposing to legalise research on human embryos not only in vitro but also in utero?
\end{abstract}

Keywords: European Convention on Biomedicine; embryo research; status of the human embryo; artificial procreation

\section{Resumé}

fuge Christian Byk rend service aux Comité directeur sur la biomédicine du Conseil de l'Europe (CDBI) en proposant une esquisse de protocole, destinée a remplir le vide juridique relatif au statut de l'embryon humain. Cette esquisse, imprimé dans le Journal of Medical Ethics, ${ }^{\prime}$ merite quelque commentaires critiques. Est-ce que Monsieur Byk propose de légaliser la recherche sur les embryons humains, non seulement in vitro, mais aussi in utero?

(Fournal of Medical Ethics 1998;24:345-347)

Mots-cles: Convention Européenne de Biomédicine; recherche sur l'embryon; statut de l'embryon humain; procréation artificielle

\section{Introduction}

The legal status of the human embryo has been discussed but not clarified. Since the Warnock committee refused to define it in 1984, it has been considered politically correct to refrain from any attempt to do so. There may be good reasons for such failure to confront and tackle difficult political problems when they concern ethics. However, the practice of artificial procreation, and related techniques such as freezing and experimenting with embryos, create such acute moral problems that an evaluation in the light of a coherent view of the staus of the human embryo seems indispensable.

If the proposed draft protocol is intended to define the status of the human embryo, one is left perplexed. The foreword makes it clear, that Christian Byk "is simply making the following suggestion: let us put aside the controversy about the legal nature of the embryo and let us suppose the the embryo could be regarded as - I do not say is - a vulnerable person". ${ }^{2}$ The proposed protocol thus pretends to clarify not what the human embryo is, but what it could be regarded as - given the political circumstances.

While this approach may be, to some extent, legitimate it is hardly satisfactory from a philosophical standpoint. It is, nevertheless, correct, as Christan Byk remarks, that "we urgently need reasonable and well-orientated public debate on the convention".

The following must be considered a contribution to this debate.

\section{Comments}

The draft protocol contains nine articles in three sections.

Of the nine articles six are protective of the vulnerable person the embryo could be said to be. The three remaining concern exceptions to the application of this protection.

\section{Section 1: object and general remarks (articles 1 - 3)}

The reader of the draft protocol is struck by the double application of the protocol. It is not only intended to regulate research on human embryos in vitro, but it also intends to regulate research on human fetuses in utero. Now, it must be presumed that this double application responds to a political demand, and it would not present any major diffi- 
culties if the draft protocol was merely protective. But as it stands, it is sad that the permissiveness relating to embryos concieved in vitro will erode the protection of embryos and fetuses conceived in utero.

Research on human embryos and fetuses in utero is established as a recognised practice, whereas it ought to be - not only for the sake of the embryo or fetus, but first and foremost for the sake of the woman's health and psychological balance - banned.

\section{Section 2: embryo and fetus in utero (articles four - five)}

Article four of the proposed draft is a fine example of the kind of legal protection the embryo or fetus conceived in utero requires:

"Article four: During pregnancy, a woman cannot take part in medical research from which her health and/or the health of the embryo would not benefit in some direct way. When the anticipated benefit exists only for the woman, the embryo or fetus must only incur the minimum degree of risk connected with this research. Furthermore, the embryo and the fetus in utero cannot be the object of research unless the aim of the research is to ensure their development and if they incur only the minimum degree of risk connected with this research."

This article actually excludes non-therapeutic and destructive research and it ensures the application of the principle of minimal risk to the embryo or fetus when the primary research object is its mother. Good paragraphs, but deceptive when complemented by article five:

"Article five: However, research with no direct benefit for the embryo or the fetus can be carried out if:

a) its therapeutic, diagnostic or cognitive outcome can be of benefit to other embryos or fetuses that are in this period of life; b) the same scientific results cannot be obtained by other means; c) the embryo or fetus only incurs a minimal risk; d) an independent committee has given its opinion on the research project and the existence of a possible conflict of interests between the woman and the embryo or the fetus; e) should there be a conflict, an "ad hoc" representative of the embryo or fetus has been appointed by the legal authority."

In the case where national legislation prescribes the destruction of the embryo subject of experiences where it has been genetically modified or where a serious risk to its healthy development can be presumed, ${ }^{3}$ all research, no matter its objective, will be indirectly detrimental to the embryo.
The notion of "therapeutic research" is applied to mean therapy for embryos other than the ores used for experiments (which are then consequently destroyed). This use of the notion $\vec{\Rightarrow}$ of "therapeutic research" undermines the respect for the individual that our societies in the West hofre fostered so carefully during more than 2000 yea $\overline{\bar{p}}$. The notion therefore needs clarification.

Section 3: embryos in vitro (articles six $\vec{?}$ nine)

The section on the embryo conceived in vipo likewise presents two fine and perceptive pa $\overline{\overrightarrow{z a}}-$ graphs protecting the human embryo conceivedin vitro:

"Article six: No embryo should be procreated vitro for the sole ends of research. ... Article seven: Research on a pre-implantation embryo (in vitro) should only be permitted if this research coubd directly benefit the embryo, in the context of grs implantation in the uterus of the woman, its later development or its state of health. The embryo should incur only the minimum degree of rigk connected with this research. ..."

But two conditional prohibitions on preservation and germ-line cell therapy leave up to the national authorities - whether this function is secured by the law, as in France, or by an inceependent authority, as in England - to decide whether embryos could be cryopreserved witha view to research and whether research on germline cell therapy could be carried out.

Moreover, article eight creates more exceptions: "Article eight: Exceptionally, research with 갱 direct benefit may be carried out on a p peimplantation embryo:

a) if it is not likely to be detrimental to it and if respects the conclusions set out in a), b), d) ande) of article five, or b) if its object is to diagnose particularly serious disorder recognised as inctable."

Again: in the case of national legislation prescriing destruction of embryos used for research, there is no way research could be non-detrimen to the embryos.

As to the fate of the "spare" embryos, 禹 following provisions are proposed:

"Article nine: Research on an in vitro embro which cannot be implanted can only be carred out if:

a) the outcome of the research is the development of techniques of medically assisted procreation or antenatal diagnosis as well as the improvement of 
knowledge in the field of pathologies that are particularly serious both for humanity and in the field of embryo-genesis; b) the research is not carried out beyond the 14th day of development; c) the research has been subjected to a scientific and ethical assesment by an independent committee."

Legalising all research on "spare" embryos for the purposes of improving assisted reproduction techniques or antenatal diagnosis, is equal to recognising the subordination of human life to the eugenic project. Many are the voices which have condemned or warned against this vast, problematic project. It is time these condemnations and warnings were faced.

\section{Suggestions and conclusion}

The following comments sum up the criticisms made in the preceding paragraphs.

It is impossible to accept the proposal for a protocol as it stands. A separation of research on human embryos and fetuses in utero and human embryos in vitro seems necessary, because of the different situation of the embryos or fetuses in question. The social consequences of widespread reseach on human fetuses in utero are almost unthinkable and, without the slightest doubt, undesirable. It will be necessary to think of the psychological and spiritual damage to the mother as well as of the planned and exploited physical destruction of the child. Therefore it seems best to treat the questions separately.

Concerning research on embryos in vitro, the notion of therapeutic research needs to be clarified, bearing in mind that it is hardly possible to designate research for the benefit of others as therapeutic research. Especially not if national legislation prescribes the destruction of embryos having served as research subjects.

Last, but not least: what we were waiting for was not a protocol relating to research on the human embryo and fetus. It was a protocol on the legal status of the human embryo. We are still in want of that.

Mette Maria Lebech is Funior Researcher at the Centre for Ethics and Law, University of Copenhagen, and Visiting Research Fellow at the Linacre Centre, Hospital of St fohn and St Elizabeth, London.

\section{References}

1 Byk C. A proposed draft protocol for the European Convention on Biomedicine relating to research on the human embryo and fetus. Fournal of Medical Ethics 1997;23: 32-7.

2 See reference 1: 2.

3 Lov om kunstig befrugtning : forbindelse med lœgelig behandling, diagnostik og forskning mv. 1997 Jun 19. (Danish law on medically assisted procreation), Lovtidende $1994 ; 84$ : $§ 27$. 